\title{
Validation of a Questionnaire on the Factors of University Failure in Morocco
}

\author{
Nada Lebkiri ${ }^{1}$, Zakaria Abidli ${ }^{1}$, Mohamed Daoudi ${ }^{1}$, Abdelmajid Soulaymani ${ }^{2}$, \\ Youssef Khatori' ${ }^{2}$, Youssef El Madhi ${ }^{2}$, Mohammed Benattou ${ }^{2}$ \\ ${ }^{1}$ Researcher, ${ }^{2}$ Professor, Ibn Tofail University, Kenitra, Morocco
}

\begin{abstract}
Objective: The objective of this researchis to develop and validate a solid and reasonablescale to measure the failure of students in Morocco.

Material and Method: This is a cross-sectional study, which took place between November 2019 and March 2020. The internalreliability of the questionnaire waschecked by calculating the Cronbach's Coefficient Index, and a factor analysis was performed.

Results: The population of ourstudyis 184 students of three masters in teaching and education, University Ibn Tofail of Kenitra-Morocco. The averageage at the time of enrollment in the first-year master's degreeis $26.59 \pm 5.65$ years. Regarding gender, wenoted that males represent a percentage of $71.2 \%(n=131)$, while females represent $28.8 \%(\mathrm{n}=53)$ with a sex ratio $(\mathrm{m} / \mathrm{f})$ of $2.4(\mathrm{p}<0.005)$. The Cronbach's alpha value for all items was 0.84 . Similarly, the calculation of Cronbach's alpha showed homogeneityacross the different dimensions of the questionnaire. For the professional curriculum $(\alpha=0.93)$, motivation $(\alpha=0.97)$, educational satisfaction $(\alpha=0.93)$, abandonment of university studies $(\alpha=0.96)$ and non-academic curriculum of students $(\alpha=0.87)$.
\end{abstract}

Conclusion: Based on the results of ourstudy, wecould, therefore, measure the academic failure of students in the education and teaching tradestreams using a questionnaire.

Keywords: Validation, questionnaires, higher education, professional insertion, satisfaction.

\section{Introduction}

The Moroccaneducation system ischaracterized by the coexistence of the public and privatesystems and French and Arabic-speakingeducation. Regarding the MoroccanUniversity cycle, isbased on the LMD system (License, Master and Doctorate) isstructuredaround 3 training cycles: License: diploma of $\mathrm{Bac}+3$ level. Master: Diploma of Bac +5 level. And PhD : diploma at $\mathrm{Bac}+8$ level. Indeed, the Moroccanuniversityeducation system has grownfrom 780,000 to 900,000 studentsfrom the academicyear 2016-2017 to 2017-2018 ${ }^{1}$. However,

\section{Corresponding Author:}

\section{Nada Lebkiri}

Ibn Tofail University, Kenitra, Morocco

e-mail: nada.lebkiri@uit.ac.ma the university dropout rate is one of the major problems of the Moroccan Ministry of Education and Higher Education. In 2018, according to the minister, more than $25 \%$ of the number of new studentsenrolled in the basic bachelor'sdegree drops out afteronly one year of training. Moreover, $43 \%$ of studentsleave the university system withoutobtaining a universitydegree, whichcouldbeexplained by severalfactors. As far as we know, no Moroccanstudies have been carried out to determine the factors of universityfailure in Morocco. For thatreason, we have constructed questionnaire to determinethesefactorsamongstudents of the master cycle in Morocco ${ }^{2,3,4,5}$. The purpose of thisstudyis to test the reliability and the validity of this questionnaire.

\section{Materials and Method}

Study Design: This is a cross-sectional study, whichtook place betweenNovember 2019 and March 
2020. The checking of the internalreliability of the questionnaire wascarried out by calculating the Cronbach's Coefficient Index 6 , then a factor analysiswas made.

Technical Sheet: A literaturereviewconcerning the determinants of motivation ${ }^{7,8}$, the satisfaction ${ }^{9,10}$, the abandonment ${ }^{11}$, professional integration ${ }^{12}$ allowed us to retainseveral items. These items have been submitted to experts in the field of universityeducation, and the heads of master training for scientific feedback and to a linguist to judge the comprehensibility of the items as thisscalewillbeintended for an Arabic-French speaking population. The opinion of these experts allowed us to discard 20 items. A total of 44 items wereretained. This questionnaire wasintended for studentswho have followed the master'sdegree course in education and teaching, itisdividedinto five dimensions:

- Professional curriculum (04 items): The first dimensionfocuses on the student'sprofessional background, theirexperiencesbefore and after the formation.

- Non-academic curriculum (03 items): This part isdedicated to the collection of information concerning the student's non-academic curriculum, certificates and attestations of training.

- Motivation (07 items): This part concerns the factors of choice of formation.

- Satisfaction (04 items): This fourth item treats the satisfaction of the students of the Master'sdegree courses.

- Abandonment (05 items): This last part isreserved for studentswho have abandonedtheirstudies; it deals mainly to the reasons for abandonment.

Besides, werealized a self-questionnaire thatcovers the socio-demographic and socio-economic information of the participants of thisstudybefore and after the registration to the master'sdegree.

- Socio-demographic situation (11 items)

- Socio-economicstatus (06 items)

Thuswedistributed the surveysheetspersonally to the students in coordination withpedagogical team. For ethicalreasons, werespected the confidentiality of the students' personal information.
Statistical Methodology: In ourresearch, the process of validation of our questionnaire wasbased on twosteps. Initially, wecalculated the reliability of the entire questionnaire and scale dimensions usingCronbach's alpha. Then, exploratory factor analyses weredone. All statistical analyses wereperformedusing the Statistical Package for the Social Sciences (SPSS) statistical software, trial version. The data collectedwereprocessed and analyzed on an exploratory basis.

In ourstudy, wecalculatedCronbach's alpha to verify the reliability and homogeneitybetween the items of the measurementscale. An alpha between 0.6 and 0.8 is acceptable for an exploratory study ${ }^{13,14}$. Wealsoused the Kayser Meyer Olkin (KMO) test. A KMO score lessthan 0.5 isunacceptable, 0.5 ismediocre, more than 0.6 is acceptable, 0.7 isaverage, 0.8 ismeritorious and 0.9 is excellent ${ }^{15}$ soweusedBartlett'ssphericity test for appreciating the potentialeffectiveness of PCA studied. For a factor analysis to befeasible, the Bartlett test must besignificant $(p<0.05)$. Principal Component Factor Analysis (PCA) is the most effective method for synthesizing information and discovering the underlying structure of a concept becauseitis a method of multivariate data analysisthatallowssimultaneous exploration of the relationshipsbetweenseveral variables of interest.

\section{Results}

Socio-demographic and professional profile of our population: The population of ourstudyis made up of 184 students of three masters degrees in teaching and educationfrom the Ibn Tofail University-KenitraMorocco. The averageage at the time of registration for the first-yearmaster'sdegreeis $26.59 \pm 5.65$ years. Concerning gender, wenoted that males represent a percentage of $71.2 \%(n=131)$, while females represent $28.8 \%(\mathrm{n}=53)$ with a sex ratio $(\mathrm{m} / \mathrm{f})$ of $2.4(\mathrm{p}<0.005)$. Urban studentsrepresent $71.7 \% \quad(n=132)$ and rural studentsrepresent $28.3 \%(n=52)$. Concerning the socioprofessional situation, wenotedthatbefore the Master's period, $23.4 \% \quad(n=43)$ of the studentswereworking as public officials and $20.7 \%(n=38)$ of the students were salaried employees. The socio-demographic characteristics of the students who participated in the survey are presented in Table 1 . 
Table 1: Socio-demographic and socio-economic profile of our population $(n=184)$

\begin{tabular}{|c|c|c|c|}
\hline Variables & Number & Percentage & P-value \\
\hline \multicolumn{4}{|l|}{ Age range } \\
\hline $20-25$ & 71 & 38,6 & \multirow{7}{*}{0.05} \\
\hline $25-30$ & 84 & 45,7 & \\
\hline $30-35$ & 13 & 7,1 & \\
\hline $35-40$ & 7 & 3,8 & \\
\hline $40-45$ & 4 & 2,2 & \\
\hline $45-50$ & 4 & 2,2 & \\
\hline $50-55$ & 1 & 0,5 & \\
\hline \multicolumn{4}{|l|}{ Rural/Urban } \\
\hline Rural & 52 & 28,3 & \multirow{2}{*}{0.05} \\
\hline Urbain & 132 & 71,7 & \\
\hline \multicolumn{4}{|l|}{ Gender } \\
\hline $\mathrm{F}$ & 53 & 28,8 & \multirow{2}{*}{0.05} \\
\hline $\mathrm{M}$ & 131 & 71,2 & \\
\hline \multicolumn{4}{|c|}{ Socio-professional situation before the Master's program } \\
\hline Students & 103 & 56 & \multirow{3}{*}{0.05} \\
\hline Public officials & 43 & 23,4 & \\
\hline Salariedemployees & 38 & 20,7 & \\
\hline
\end{tabular}

\section{Validation of the questionnaire:}

Internalconsistency of questionnaire items: The Cronbach's alpha value for all items was 0.84 . Similarly, the calculation of Cronbach's alpha showedhomogeneityacross the different dimensions of the questionnaire. For the professional curriculum $(\alpha=0.93)$, motivation $(\alpha=0.97)$, educational satisfaction ( $\alpha=0.93$ ), abandonment of universitystudies $(\alpha=0.96)$ and non-academic curriculum of students $(\alpha=0.87)$. Table 2 shows all of theseresults.

Table 2: Cronbach's alpha values of all items and dimensions of the questionnaire

\begin{tabular}{|l|c|c|}
\hline & $\begin{array}{c}\text { Cronbach's } \\
\text { Alpha }\end{array}$ & $\begin{array}{c}\text { Number of } \\
\text { items }\end{array}$ \\
\hline Item Sets & 0,84 & 23 \\
\hline Professional Curriculum & 0,93 & 4 \\
\hline Motivations & 0,97 & 7 \\
\hline Satisfaction & 0,93 & 4 \\
\hline Abandonment & 0,96 & 5 \\
\hline Non-academic curriculum & 0,87 & 3 \\
\hline
\end{tabular}

Factor analysis: To make a factorialanalysis of the questionnaire wetookintoconsideration the value of the KMO index and the Bartlett sphericity test. For ourstudy, the KMO index was $0.85>0.5$ which shows an acceptable value for factor analysis. The Bartlett sphericity test washighlysignificant.

Table 3: KMO index and Bartlett test

\begin{tabular}{|l|l|c|}
\hline \multicolumn{2}{|l|}{ Value } & \multicolumn{2}{|l|}{0,85} \\
\hline \multicolumn{4}{|l}{ Precisionmeasurement of Kaiser-Meyer-Olkin sampling. } & 5797,51 \\
\hline \multirow{3}{*}{ Bartlett Sphericity Test } & Approximate Chi-square & 253 \\
\cline { 2 - 3 } & ddl & $<0,00$ \\
\cline { 2 - 3 } & Meaning of Bartlett & \\
\hline
\end{tabular}

Factor analysis in the main axes withvarimax rotation showed that five factors in the eigenvalues are higherthan 1 explain $88 \%$ of the total variance. The five dimensions are welldefined and distinct on the respective factors: the first factor, whichincludes four items (EX_1, EX_2, EX_3, EX_4) constituting the professionalexperience dimension, explains $29.03 \%$ of the total variance. The second, withseven items (WORD_1, WORD_2, WORD_3, WORD_4, WORD_5, WORD_6, WORD_7) constituting the dimension of student motivation, explains
$21.83 \%$ of the total variance. As for the third factor, with four items (SAT_1, SAT_2, SAT_3, SAT_4), explains $14.87 \%$ of the total variance, constituting the dimension of student satisfaction with the master'sdegree course in Educational and Teaching Professions. For the fourth factor, whichincludes five items (ABD_1, ABD_2, ABD_3, ABD_4, ABD_5) constituting the dimension thatisrelated to the students' satisfaction, whichexplains $13.59 \%$ of the total variance. Table 4 represents the cleaned component matrix. 
Table 4: Component matrix cleaned

\begin{tabular}{|c|c|c|c|c|c|}
\hline & & & mpon & & \\
\hline & 1 & 2 & 3 & 4 & 5 \\
\hline EX_1 & & & &, 724 & \\
\hline EX_2 & & & & 694 & \\
\hline EX_3 & & & &, 723 & \\
\hline EX_4 & & & & 676 & \\
\hline MOT_1 & ,961 & & & & \\
\hline MOT_2 &, 874 & & & & \\
\hline MOT_3 &, 890 & & & & \\
\hline MOT_4 & ,903 & & & & \\
\hline MOT_5 & ,937 & & & & \\
\hline MOT_6 & ,935 & & & & \\
\hline MOT_7 & ,904 & & & & \\
\hline SAT_1 & & & ,791 & & \\
\hline SAT_2 & & & ,877 & & \\
\hline SAT_3 & & &, 841 & & \\
\hline SAT_4 & & & ,797 & & \\
\hline ABD_1 & &, 838 & & & \\
\hline ABD_2 & &, 784 & & & \\
\hline ABD_3 & &, 807 & & & \\
\hline ABD_4 & &, 787 & & & \\
\hline ABD_5 & &, 796 & & & \\
\hline NA_1 & & & & & 628 \\
\hline NA_2 & & & & &, 764 \\
\hline NA_3 & & & & & ,769 \\
\hline
\end{tabular}

\section{Discussion}

University formation is one of the most important elements in the economicdevelopment of a country. Over the last few years, increasing attention has been paid to the social role and the impact of researchcarried out in universities. This isconfirmed by ourstudy:everyyear, universities take in new students and graduateothers; in thiscontinuous cycle, the quality of educationoccupies a crucial place. Therefore, increasing the quality of the education system isconsidered to be the mostinfluential factor in the development of countries. Studentsacquire, throughtheiracademicsuccess, a position in whichtheir maximum internal and external strengths are used to achieve the objectives of highereducation and to obtain the necessary conditions for a successful social life. On the other hand, the lack of success in education opens the way to severalpersonal and social problems and deviationsfrom the achievement of the objectives of the education system ${ }^{16}$. In this regard, one of the major problems of highereducation establishments is the academic failure of students at all levels of education, which not only leads to a loss of currentexpenses and time, but also generates psychological, social and familyproblems for university students. According to studies, this problem is aggravating every year, so that many students are unable to follow the program (academic curriculum) or to completeit on time ${ }^{17}$. Academic failure includes various aspects such as frequent absence from classes, dropping out, repeat grades or poorquality of teaching ${ }^{18}$. UNESCO attributes the concept of academic failure to repetition, early dropout and declining quality of learners' education ${ }^{19}$. 
Concerning our study, to determine the factors of the academic failure of students enrolled in the master'sdegree in education and teaching professions, we used Churchill's method ${ }^{20,21}$ whichisused in several areas. The questionnaire that has been developed contains several dimensions to gain a better understanding of the concept of failure. This questionnaire focuses on several dimensions such as academic and non-academic factors, professional career and student motivation, as they are one of the primary factors that cause academic failure according to several studies ${ }^{22}$.

Various research have determined the relationship between addiction to psychoactive substances (cigarettes, alcohol...) $)^{23}$ and university failure ${ }^{24}$ that we didn't mention in ourstudy for socio-cultural reasons. Similarly, a study made by an America n University among people who committed suicide indicated that academic failure was the most common cause of their death $^{25}$. Various studies have shown that personality factors, motivation, interest, satisfaction, loneliness, the expectation of success, and family circumstances can affect the level of academic success in universities. In a comprehensive approach, the factors involved in academic failure can be classified into three categories, (i) individual factors (components such as having a goal, motivation, anxiety, method of study, intelligence, attention, planning, emotional and mental conditions, lack of attendance, motivation, anxiety, method of study, intelligence, attention, planning, emotional and mental conditions and the lack of class attendance, emotional and mental conditions and the lack of class attendance), (ii) internal organizational factors (professional characteristics of instructors, space and appropriate facilities and equipment) (iii) external organizational factors (parents' level of education and how they cope with students' academic failure, socio-economic status of families and uncertain career prospects) ${ }^{26,27,28}$. These factors are in harmony with the dimensions of our questionnaire.

\section{Conclusion}

This studyaims to identify the factorsthat affect academic failure from students in the master's cycle in teaching and education and the professional integration of students. Our future work is no woriented towards calculating the results of this experiment. This will allow us to have a view on the university failure rate in Morocco.
Remerciements: Wewould like to thank all the studentswhoparticipated in the study, as well as the Dean of the Faculty of Sciences of Kénitra and the Dean of the Faculty of Letter and Human Sciences of Kénitra for authorizing us to use the data from the APOGEE system.

\section{Ethical Clearance: No}

Source of Funding: Evaluation of training systems for teaching and education in Morocco - Towards a new perspective for the validation of priorlearning. Ibn Khaldun Program to Support Scientific Research in the Human and Social Sciences - IK/2018/50

\section{Conflict of Interest: Nil}

\section{Reference}

1. Higher Council of Education, Training and Scientific Research of Morocco. Higher Education. 6 janv2020;Available on: https://www.csefrs. $\mathrm{ma} / \mathrm{wp}$-content/uploads/2018/10/RapportEnseignement-sup--rieur-Fr-03-10.pdf.

2. Economic, Social and Environmental Council, CESE. (2016). Global Wealth of Morocco between 1999 and 2013.

3. Higher Council for Education, Training and Scientific Research, CSEFRS. (2017). Evaluation of PolydisciplinaryFaculties:Whatpolicy, what impact and what perspective?

4. Higher Council for Education, Training and Scientific Research, CSEFRS. (2018). Promotion of education, training, management and research professions.

5. Debbarh A. Personnel enseignant de l'enseignement supérieur universitaire Situation Actuelle et perspectives à l'horizon 2020: cas du Maroc. SminaireRgional Tempus sur la Gestion des Ressources Humaines dans lEnseignementSuprieur dans les pays du sud de la Mditerrane Nicosie. 2013.

6. Cronbach LJ. Coefficient alpha and the internal structure of tests. Psychometrika. sept 1951;16(3):297-334.

7. Viau R. La motivation des étudiants à l'université: mieux comprendre pour mieux agir. In: Conférence non publiée. 2006.

8. FORNER Y. La motivation à la réussite scolaire dans les situations de formation: QMF Manuel. Issy-les-Moulineaux: Éditions des EAP. 1993. 
9. Kahombera R, Duranton F. SATISFACTION DES ETUDIANTS DANS UNE INSTITUTION D'ENSEIGNEMENT UNIVERSITAIRE. 2018.

10. Carayon S, Gilles P-Y. Développement du questionnaire d'adaptation des étudiants à l'université (QAEU). L'orientation scolaire et professionnelle. 2005;(34/2):165-89.

11. Beaupère N, Boudesseul G, Macaire S. Sortir sans diplôme de l'Université. Comprendre les parcours. 2009.

12. Mourji F, Gourch A. Modélisation de l'insertion professionnelle des diplômés de l'enseignement supérieur au Maroc. Critique économique. 2008;(22).

13. DMSP Research Centre. Proposition of a contextualizedscale of measurement team learning: An ExploratoryAnalysis. Université de ParisDauphine, Paris, France. 2003. [cited 10 juin 2019]. Availableon:https://basepub.dauphine. $\mathrm{fr} /$ bitstream/handle/123456789/4299/CR321. pdf $\% 3$ Bsequence $\% 3 \mathrm{D}$.

14. Johnson RA. Wichern. DW AppliedMultivariateStatisticalAnalysis. New Jersey:Prentice-Hall, lnc. 2007;1:998.

15. Stewart DW. The application and misapplication of factor analysis in marketing research. Journal of marketing research. 1981;18(1):51-62.

16. Hazavehei SMM, Fathei Y, Shamshirei M. Study on the causes of students' academic probation in HamadanUniversity of Medical Sciences, 20012002. Strides in development of medicaleducation. 2006;3(1):33-42.

17. Pagani L, Boulerice B, Vitaro F, Tremblay RE. Effects of poverty on academic failure and delinquency in boys: A change and process model approach. Journal of Child Psychology and Psychiatry. 1999;40(8):1209-19.

18. McEvoy A, Welker R. Antisocial behavior, academic failure, and schoolclimate: A criticalreview. Journal of Emotional and Behavioral disorders. 2000;8(3):130-40.

19. Delors J. Learning: The Treasurewithin. Report to UNESCO of the International Commission on Education for the twenty-first-Century, Paris UNESCO 1996. Internationales Jahrbuch der Erwachsenenbildung. 1996;24(1):253-8.

20. Churchill Jr GA. A paradigm for developing better measures of marketing constructs. Journal of marketing research. 1979;16(1):64-73.

21. Fabrigar LR, Wegener DT, MacCallum RC, Strahan EJ. Evaluating the use of exploratory factor analysis in psychologicalresearch. Psychologicalmethod. 1999;4(3):272.

22. Najimi A, Sharifirad G, Amini MM, Meftagh SD. Academic failure and students' viewpoint: The influence of individual, internal and externalorganizationalfactors. Journal of education and health promotion. 2013;2.

23. Abdulrazzaq N, Kamal M, Muhsen A, Tareq A, Al Zubaidi R, Al Mousawi A. Academic failure and students' viewpoint: The influence of individual, internaland externalorganizationalfactors. Scientific Journal of MedicalResearch. 2017;1(1):1-5.

24. Younge SL, Oetting ER, Deffenbacher JL. Correlationsamongmaternal rejection, dropping out of school, and drug use in adolescents: A pilot study. Journal of Clinical Psychology. 1996;52(1):96-102.

25. Meilman PW, Pattis JA, Kraus-Zeilmann D. Suicide attempts and threats on one collegecampus: Policy and practice. Journal of American CollegeHealth. 1994;42(4):147-54.

26. Fan $X$, Chen M. Parental involvement and students' academic achievement: A meta-analysis. Educational psychology review. 2001;13(1):1-22.

27. Rivkin SG, Hanushek EA, Kain JF. Teachers, schools, and academic achievement. Econometrica. 2005;73(2):417-58.

28. SafdariDehcheshmeh F, Delaram M, Parvin N, Kheiri S, Forouzandeh N, Kazemian A. The viewpoints of students and educators, in faculty of nursing and midwifery of ShahrekordUniversity of Medical Sciences, about the effective factors in academicimprovement of students, 2004. Journal of Shahrekord Uuniversity of Medical Sciences. 2007;9. 